\title{
Assessing the Effectiveness of e-Government and e-Governance in South Africa: During National Lockdown 2020
}

\author{
P.P. Blom ${ }^{1} \&$ D.E. Uwizeyimana ${ }^{1}$ \\ ${ }^{1}$ School of Public Management, Governance and Public Policy, University of Johannesburg, Johannesburg, South \\ Africa \\ Correspondence: D.E. Uwizeyimana, School of Public Management, Governance and Public Policy, University of \\ Johannesburg, Johannesburg, South Africa. E-mail: dominiqueu@uj.ac.za
}

Received: May 13, 2020

Accepted: June 18, 2020

Online Published: September 3, 2020

doi:10.5430/rwe.v11n5p208

URL: https://doi.org/10.5430/rwe.v11n5p208

\begin{abstract}
This article aims to assess the effectiveness of e-Government and e-Governance service during the national lockdown in South Africa. The focus of this article is on e-Health, e-Education and e-Municipal Services delivery, as these are the most sought-after e-Services during the national lockdown caused by COVID-19 (coronavirus) pandemic in 2020. Education, health, and municipal services are some of the core functions that could not be paused during the lockdown due to their importance. The methodology used in this research is mainly qualitative. Unobtrusive research techniques based on documentary and theoretical analysis will be applied to assess the state and use of e-Government and e-Governance within the public sector during the national lockdown in South Africa. The findings of this article suggest that government failed to achieve its objective of building an inclusive Information and Communication Technologies (ICTs) infrastructure in South Africa. Even though steps have been taken by the government to provide free access to basic e-Services, network coverage, and ICT infrastructures, poverty and inequality remain the major challenges in rural areas. The findings of this research suggest that the South African government needs to build ICT infrastructures in rural areas and to provide citizens with training on how to utilise ICT infrastructures in order to reduce the gap between rural and urban areas.
\end{abstract}

Keywords: e-Government, e-Governance, Information and Communication Technology (ICT), Fourth Industrial Revolution (4IR), service delivery, e-Service, government

\section{Introduction}

The Third Industrial Revolution (TIR) was steered largely by technological developments in processing, storage, and energy production factors that contributed to increased automation, and increased use of computers and electronic devices. The TIR had a major transformational effect on various sectors such as ICT, defence, health, education, engineering, banking, and administration. The use of electronic technology can be regarded as the main characteristic of the TIR. The South African government took advantage of the ICTs infrastructure to enhance the provision of goods and services. As the government increased the use of ICTs to address the highly diverse, challenging, and complex needs of South African citizens, the ICT transformed the way the government functions and increased citizens' participation in societal and government matters. The purpose of this article is to assess the effectiveness of e-Government and e-Governance services during the national lockdown in South Africa.

To achieve the objective of this article, the authors will firstly conceptualise the e-Government and e-Governance within the South African perspective. The article will proceed by identifying three e-Government and e-Governance services that continued to function during the national lockdown and then use them to discuss the implications of e-Government and e-Governance in South Africa during national lockdown. The article will conclude by highlighting the challenges and the benefits of e-Government and e-Governance in South Africa during national lockdown caused by the COVID-19 pandemic in 2020.

\section{Conceptualising e-Government and e-Governance}

E-Governance and e-Government concepts are mostly used interchangeably and synonymously in literature, but they have distinctive meanings and differences. According to Chen, Dawes and Chen (2017:330), e-Government refers to the usage of Information and Communication Technologies (ICTs) and automated devices by the government to 
deliver services to the citizens and other stakeholders, within and outside the country's boundaries effectively and efficiently. The electronic networks created by these interactions are known as Government-to-Citizen (G2C), Government-to-Government (G2G) and Government-to-Business (G2B). The ICT infrastructures may vary from department to department and sector to sector, but the main objective is to deliver services in an efficient and effective manner (Department of Telecommunication and Postal Services (DTPS 2017). Government needs to adequately plan the e-Government so that it can be effectively implemented to enhance service delivery, cost savings, and increase citizens' level of participation and involvement (Ntulo \& Otike 2013:1).

E-Governance is the mechanism of transforming the way government operates, engages with citizens, and provides services to citizens (Uwizeyimana 2015:152). E-Governance comprises e-Democracy, e-Service, and e-Citizen to empower citizens to take part in policy decisions. E-Governance effectively provides people with online tools for accessing government resources and information (Rimjhim \& Kumar 2018). Providing services electronically is called e-Service. The ability to provide e-Services to the citizens is particularly important in rural areas of developing countries such as South Africa because that is where most poor people live. People in rural areas of developing countries are facing many challenges, such as lack of transport infrastructure, which make it difficult and expensive to travel to the government offices because they are located far from the villages where most of the citizens live (Uwizeyimana 2015:153). Figure 1 portrays the difference between e-Government and e-Governance.

\begin{tabular}{cc}
\hline \multicolumn{2}{c}{ e-Government and e-Governance } \\
\hline SUPERSTRUCTURE & GOVERNANCE \\
\hline Decisions & Functionality \\
\hline Rules & Processes \\
\hline Roles & Goals \\
\hline Implementation & Performance \\
\hline Outputs & Coordination \\
\hline E-GOVERNMENT & E-GOVERNANCE \\
\hline Electronic service delivery & Electronic consultation \\
\hline Electronic workflow & Electronic controllership \\
\hline Electronic voting & Electronic engagement \\
\hline Electronic productivity & Networked societal guidance \\
\hline Figure 1. The difference between e-Government and e-Governance
\end{tabular}

Source: Singh 2017: internet source

There "era of e-Government, which is about using information and communications technologies to bring efficiencies to government" has been with us since the beginning of the last decade (PSA 2019:1). Uwizeyimana (2015:151) argues that e-Government is about "using technologies to improve the ease of connection between government and the citizens". E-government will improve government processes and the connection between government and the citizens. The improved connection between government and the citizens will improve the overall public service delivery (Nalubega \& Uwizeyimana 2019). E-government will remove the division between rural and urban because citizens will be able to access public services electronically via their electronic devices such as smartphones, irrespective of where they stay in the country (Uwizeyimana 2015).

It is commonly accepted that e-Government is a result of the digital revolution that started during the Third Industrial Revolution (TIR) (early 1950s to early 2000s) and continued through the Fourth Industrial Revolution (4IR) (since early 2000s to this day) (PSA 2019:1, Uwizeyimana 2020a:4).

An industrial revolution (IR) is a phenomenon of transition from the current era to a more revolutionised society (Vries 2008:158). People were generally resistant to change at the beginning of IR because they were accustomed to the way things were done. However, as the IR started to affect people in a positive manner, their attitude changed, which led to increased adaptability of IR. There are few, if any families anywhere in the world, in rural and urban areas of developed and developing countries, which do not enjoy the benefits of communicating to others in the comfort of their homes because of the mobile phone technology. "Today Africa boasts over a billion sim-card connections with an $80 \%$ subscription penetration" (White \& Rees 2019:1). Since the past two decades, mobile phones (or cell phones), radios, TVs, and other electronic forms of media outlets and technologies have become the 
main source of information and education (Xing \& Marwala 2007:1), even among traditional societies in remote rural areas of Africa (Uwizeyimana 2020:6).

There is no doubt that any IR that has taken place at any given time has influenced the way people live, travel, work and communicate (Roberts 2015:1). But the TIR and the 4IR have most probably influenced the way people live, travel, work and communicate in a more fundamental way than other industrial revolutions.

The TIR (also known as the Digital Revolution), had a considerable influence on the world (Roberts 2015:2). The TIR, was characterised by the "development of semiconductors and mainframe computing (1960s), and "other technological inventions of this era included personal computing (1970s and 80s) and the internet (1990s)" (Schwab 2016:11, cited in Uwizeyimana 2020a:4). The electronic devices created during the TIR were credited for kick-starting and facilitating e-Government. Therefore, the growing use of cloud computing and automation of back-office processes during the 4IR is one of aspects of e-Government development (PSA 2019:4). There is a consensus among academics such as Schwab (2017:3), Xing \& Marwala (2017:11); Xing, Marwala \& Marwala (2018:171) and Nalubega \& Uwizeyimana (2019:4) that the 4IR is:

"a fusion of disruptive technologies that are blurring the lines between the physical, digital, and biological spheres" and that these fusions of disruptive technologies are mainly the transformative, scientific and technological advances presented in various fields such as advanced robotics, AI, drones, the IoT, wearables, additive manufacturing or three-dimensional (3D) printing, driverless cars, blockchain technologies, bioscience technologies, augmented reality (AR) and virtual reality (VR), etc."

There is also an agreement that no one can be spared from the influence of the 4IR technologies which are shaping and reshaping the way people live, work and relate to one another" (Schwab 2017:3).

There is no doubt that every IR had a transformative effect on the people who lived during and beyond its era. There is also no aspect of life that will escape the disruptive effects of 4IR technologies. Shaped by automated infrastructure, such as robots with the capacity to learn and perform the work that is naturally performed by human beings, and powered by high capacity superfast internet connections (online), massive changes and improvements will inevitably happen within different fields, including, but not limited to economics, manufacturing, education, health, agriculture, and public governance and public service delivery etc. With time, people will eventually get accustomed to 4IR technologies, such as the Internet of Things (IoT), driverless transportation, and hopefully technological innovations brought on by these industrial revolutions (Kayembe \& Nel 2019:81) will improve their lives.

However, while most people are already accustomed to new technological materials such as computers, portals, social media, intranets, 3G network coverage, $\mathrm{Wi}-\mathrm{Fi}$, smart devices, telecommunication frequency, which were launched during TIR era; there is a consensus that the 4IR is going be the most challenging era in terms of how it revolutionises traditional management and governance norms in the public and private sector globally. It is also commonly accepted that any government which does not embrace the 4IR technologies will most likely not be able to develop its own people (Nalubega \& Uwizeyimana 2019:1). The South African government acknowledges the importance, necessity, and value of using 4IR technologies, such as internet access, to execute its statutory functions effectively, efficiently, and economically (PSA 2019:1).

\subsection{E-Governance and e-Government Within the South African Perspective}

In South Africa, "the e-Government programme started informally in 1999 after the publication of the PRC report (1998)" (DPSA. 2001:1). The South African government established the ICT agency called the State Information Technology Agency (SITA) in 1999 in order to enhance service delivery, ensure the inclusion of all citizens and improve cooperation between government, community, stakeholders, and various partnerships (Shafika 2007:7). Currently, according to the PSA (2019:4), "the South African government has a Draft National e-Government Strategy, whose objectives are to digitise government services" which was released in 2017. According to the DTPS (2017), the aim of the South African Government is to use this strategy "to optimise service delivery that provides universal access to government information and services anytime and anywhere" in the geographical area of South Africa and beyond.

The government of South Africa is following the example of many governments around the world, which have taken advantage of e-Services to fulfil its task in a secure, reliable, and cost-effective way (Cloete 2012:128). According to the PSA (2019:4), one of the countries that the South African government is trying to imitate is Estonia. Over " $99 \%$ of the public services are available online" in Estonia and the digitised public services in that country are accessible 24/7 anywhere in the world (PSA 2019:4). For example, because of the widespread high-speed data connectivity, Estonia's "health care registry and pretty much everything else that concerns the data of patients or citizens is run on a blockchain, which gives power to citizens to own their data wherever they are in the world" (PSA 2019:4). 
Blockchain is "an encrypted platform or distributed ledger that captures transactions and records of proofs of ownership and is managed by a peer-to-peer network" (Nalubega \& Uwizeyimana 2019:13). Blockchain is "the technology that underpins cryptocurrency or bitcoin, although as a distributed ledger, it has a life of its own outside of bitcoin, and can be used to store certificates, title deeds, medical records etc." (Nalubega \& Uwizeyimana 2019:13). E-Government is so advanced and popularly used by almost every Estonian citizen to the point that "the only aspects of the public services that are outside e-Government in Estonia and require physical interface are those to do with marriages, divorces and real estate transactions, but everything else is nearly $100 \%$ digitised" (PSA 2019:4). Not only have the new technologies that are associated with the 4IR in the domain of government services facilitated easy and fast access to public services in Estonia, they have also facilitated greater transparency (PSA 2019:4). There is evidence that the application of 4IR technologies in the provision of public goods and services will assist government to tick all the boxes of good governance such as accuracy, efficiency, less corruption, accountability, economy and effectiveness to name but a few (Uwizeyimana \& Maphunye 2014:90). As Uwizeyimana and Basheka (2017:9) put it, we are in the era in which "E-Governance is fast moving to embrace the requirements of the 4th Industrial Revolution".

South Africa is not far behind in utilising e-Services to reduce difficulties faced by government and residents. For example, the South African government has introduced e-Natis, an electronic transport management system, which allow users to book drivers' license testing for learners and has established a new public driving permit online. There is also an e-Justice platform whose objective is to improve access to judicial service (Naidoo 2007).

According to the Department of Telecommunications and Postal Services (2017), the South African government assigned jurisdiction to different legislation, regulatory systems and ICT services in order to better manage and control e-Government and e-Governance in all the spheres of government. The White Paper on the Transformation of Public Service Delivery (Notice 1459 of 1997, (WPTPSD), The Electronic Communications and Transaction Act 25 of 2002, the Minimum Information Security Standards (MISS), Minimum Interoperability Standards (MIOS) and Policy on Free and Open Source Software (FOSS) are just some of the frameworks that foster openness, accountability for good governance, information security and the liberty to acquire and use ITCs in South Africa.

The State Information Technology Agency (SITA) and Government Information Technology Officers Council (GITO Council), are entities administered by government to oversee the execution of e-Government programmes on the behalf of the South African government. Their roles range from implementing and preserving IT infrastructures in all government sectors, consolidating, and integrating IT activities in all government departments and agencies and promoting the provision of e-Services to all South African citizens. The Promotion of Access to Information Act, 2000 or (PAIA) provides for the fundamental right to access to information. It entitles citizens to seek information from a public or private agency (Department of Telecommunications and Postal Services 2017). The e-Government delivery models in South Africa are displayed in Figure 2.

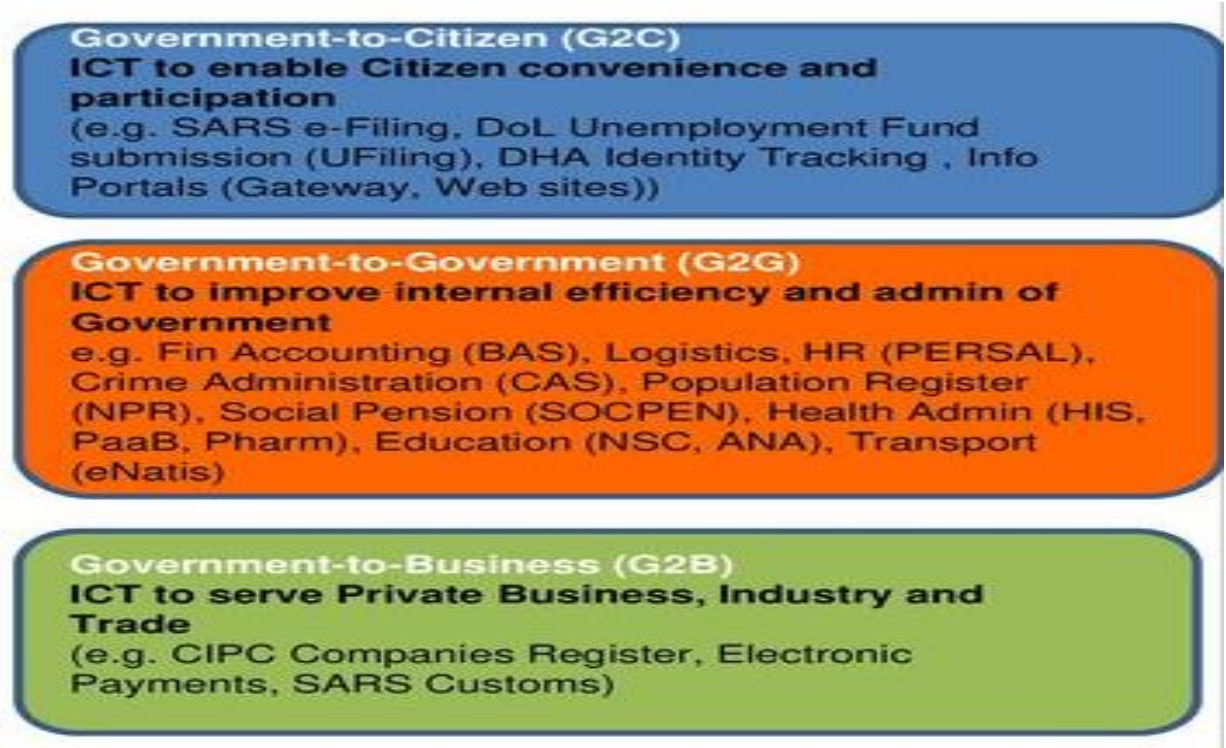

Figure 2. The e-Government delivery models in South Africa

Source: Department of Telecommunication and Postal Service 2017:31) 


\subsection{Benefits of Using e-Government and e-Governance in South Africa}

There are many benefits of using e-Government and e-Governance in any country. Initiatives such as Government-to-Citizen (G2C), Government-to-Government (G2G) and Government-to-Business (G2B) were introduced in order to ensure efficient service delivery and to facilitate collaboration between the South African government and its private and public stakeholders (DTPS 2017). With the implementation of e-Services, various departments in all three government spheres (national, provincial, and local governments) have been transformed (Karunasena, Deng \& Singh 2011).

One of the benefits of e-Government is that it allows citizens to access public services through gadgets such as mobile phones from anywhere in the country on an unlimited basis (24/7). According to Statistics South Africa (2020), there were about 36.54 million internet users, of which 34.93 million were mobile internet users, in South Africa in January 2020. These statistics mean that many South Africans had the means to access e-Services via their mobile devices. They could also have used their devices to access services such as paying municipal accounts and to access e-Learning for their children who were at home as the schools were closed during the lockdown. Most South Africans were able to access e-Health portals during the lockdown. For example, the South African government was able to run its "Stay Home, Stay Safe" campaign and to provide vital information related to COVID-19 to almost everyone with a mobile telephone number anytime and anywhere in the country. People were encouraged to join the Government WhatsApp group number 0600123456, they could check their COVID-19 symptoms through Government's official HealthCheck system by dialling a toll free number $* 134 * 832 \#$ and millions of people were able to get COVID-19 information or to apply for disaster relief assistance via government websites.

E-Government and e-Governance is not limited to the national government. For example, the City of Johannesburg Metropolitan Municipality (or COJ) launched an e-Learning system, which has two components. The first component facilitates residences' interaction with the municipal leadership and the second component is designed to provide education empowerment. The statistics from the portal which provides free access for e-Learning resources such as e-Books, and free education websites, show that the number increased from 14,000 in 2017 to 56,320 in 2018/2019 (City of Johannesburg IDP 2019).

There is no longer any doubt that e-Government and e-Governance increases the quality and efficacy of public service delivery. The study titled "e-Government in South Africa: Predictors to failure and success", which was conducted by Kiren Pillay in 2012 shows that 73 percent (\%) of people sampled agreed that the e-Service (e-Natis) improved their performance at work and 100 percent agreed that using e-Natis would increase their productivity (Pillay 2012:69). There is also evidence that e-Government and e-Governance increase transparency, improve communication between government and the citizens and empower the citizens by providing them with the information they need to hold their governments accountable. According to Corruption Watch (2019), e-Technology can reduce loopholes of bribery in many institutions. For example, when an employee wants to claim for unemployment compensation, she/he will submit all the documents online, all payments are deposited into one bank account, managed by the National Department of Labour. This means that the department will be forced to assess the application according to the standards and criteria that can be verified by the public or anti-corruption institutions.

\section{Effectiveness of e-Government and e-Governance Services During the South African National Lockdown}

On 23 March 2020, the State President, Honourable Cyril Ramaphosa declared that the country will undergo a national lockdown for 21 days (26 March -16 April 2020), as a mechanism/strategy to reduce the spread of the Coronavirus (COVID-9) pandemic (Ramaphosa 2020). The country has been under the national lock down for approximately four months at the time of writing this article in June 2020. Hence the objective of this article is to analyse the effectiveness of e-Government and e-Governance services during the South African national lockdown. Effectiveness is concerned with the degree of success or failure to achieve the hoped-for objectives or outcomes (Uwizeyimana 2011:75). The concept effectiveness, as used in this article, refers to the use of e-Government and e-Governance services delivery methods to provide e-Services to the South African citizens in an effective manner during the national lockdown. The following sections explore the delivery of e-Education, e-Health and e-Municipal services during the national lockdown.

\subsection{E-Education (Basic Education)}

E-education entails using ICT infrastructures to promote the attainment of national educational objectives by using ICT infrastructures to create virtual classes by linking learners, teachers, and educational programmes (Department of Education 2003). Put simply, e-Education/e-Learning is the provision of teaching instructions and the facilitation of learning through electronic methods (UNPA \& ASPA 2001). E-Education has been applied successfully in some 
private schools because they have adequate ICT infrastructures to provide e-Services efficiently (UNPA \& ASPA 2001). However, e-Learning is still a major challenge in many South African public schools, particularly in rural areas due to minimal or lack of ICT and other infrastructures such as electricity, computers, and Wi-Fi connectivity (Letseka, Letseka \& Pitsoe 2018). There is evidence that government attempts to improve e-Learning have not yielded the expected results. The Department of Basic Education launched the e-Education program in 2004, with the aim of transforming learning and teaching, and keeping up to date with evolving technological revolution (Department of Education 2004). However, 16 years later, since the launch of the White Paper on e-Education, the goal to ensure that all schools within South Africa benefit from e-Education has not materialised. In addition, in 2013 Cabinet made the conscious decision to provide ICT capability in schools by delivering 90 percent (\%) broadband access by 2020 and 100 percent by 2030. The government has not met half of the 2020 target, which raises doubts about whether it will be able to achieve the 2030 goals in the remaining nine years. E-Learning remains difficult, and to some extent impossible in South African public schools, because of lack of access to Wireless internet, lack of computers and other ICT equipment, and poor or no practical training for both educators and learners (Mathevula \& Uwizeyimana 2014:1087).

Despite all these challenges that the country is facing, most learners (basic education and students (tertiary education)) utilised the use of e-Learning (online platforms) for learning, assessment and communicating with teacher and lectures. Since the beginning of the national lockdown in March 2020, e-Education has been largely accessible to students and more resources were allocated to try to meet the need of learners and students. Both the Department of Basic Education (DBE) and the Department of Higher Education and Training (DHET) worked in partnership with the private sector and numerous telecommunication service providers to allow learners and students to access the website of the departments of education and university websites to download the education content free of charge. In addition, some universities, such as the University of Johannesburg went as far as providing free 30 Gigabytes of data to all registered students, and thousands of free electronic devises (laptops) were provided to deserving students. Teaching and learning continued throughout the lockdown via WhatsApp, emails, Blackboard, collaborate Ultra, Microsoft team and all formative and summative assessments (except practical) were conducted online. According to Reddy (2020), Marnewick team provided free online classes from Monday to Friday to over 650000 primary school learners from grade 1 to grade 9.

Some of the e-Learning initiatives of the Department of Basic Education include the following:

- Access to Vodacom's e-Learning school for free educational content for all grades.

- MTN provided zero-rated online resources on siyavula.com.

- Microsoft offered students free access to Office365 by visiting mahala.ms.

- DStv's mindset program,

- Broadcast lessons (SABC TV and radio); and

- 2Enable App, a freely downloadable education platform with over 2000 electronic readers in the African languages (Department of Education 2020).

A report from Vodacom shows that over 40,000 learners visited its e-School platform per day since the national lockdown (Hlangani 2020). In addition to the DBE and telecommunication companies' initiatives, some well-managed public primary schools such as Laerskool Dalmondeor Primary School continued to provide e-Learning by sending lessons and assessments to their learners on a daily basis via the school WhatsApp. Of course, it is inevitable that some students were not able to benefit from e-Learning because of lack of ICT infrastructures. It is also inevitable that some teachers could have decided to use the national lockdown as an extra holiday period. Others thought that continuing classes via e-Learning will disadvantage poor children and decided to do nothing for everybody. However, even though some public schools thought they are helping the poorer children by doing nothing for everybody, the children from well-off families continued to access free e-Learning material from e-Learning initiatives of the Department of Basic Education discussed above. The best way to deal with inequalities at these public schools would have been to find means to provide electronic devices to the children from poor families so that they can be at the same level with children from well-off families. The examples above prove that e-Learning can be an effective means to educate South African children, if government was able to avail ICT infrastructure to schools and students and to collaborate with private stakeholders and telecommunication companies in the same way it did during the lockdown in 2020. 


\begin{tabular}{lll} 
Name of institution & Type of access & Statistics \\
\hline Vodacom & Free access to the Vodacom Virtual Classroom & 1 million + \\
\hline MTN & $\begin{array}{l}\text { Free access to Siyavula Maths and Science support } \\
\text { via MTN network }\end{array}$ & No data released so far \\
\hline Sasol & $\begin{array}{l}\text { online lessons, virtual class and reading club grade } \\
\text { R-12 }\end{array}$ & $45000+$ \\
\hline Maverick Daily & Online classes in different subject grade 1-9 & $650000+$ \\
\hline
\end{tabular}

Figure 3. Examples of institutions offering free access to online learning

Sources: Figure 3 created by authors.

\subsection{E-Health}

The official South African e-Health strategy was only released in 2012, but since the early 2000s, the Department of Health $(\mathrm{DoH})$ has been using e-Health systems to treat patients that have been diagnosed with HIV and TB (DoH 2019). According to the World Health Organisation (WHO 2019), e-Health is the convergence of medical information technology, public health and industry. E-Health also relates to health programmes and knowledge provided or improved through internet and associated technologies (WHO 2019). The primary objective of e-Health is to develop healthcare on a national scale using ICTs (WHO 2019). The increased use and availability of mobile technology in developing countries has led to the development of m-Health. M-Health is the use of mobile cell phones, digital technologies and devices for medical practice and public health services in the health sector (DoH 2019). M-Health encompasses educating and engaging in comprehensive health care programs for residents (DoH 2019). According to Barron and Peter (2018), the most popular example of e-Health is, MomConnect, the SMS-based communication app that was introduced in 2014 to provide information and guidance to mothers from birth to the first few years of their baby's life.

E-Health has been working effectively since the national lockdown and was used to reduce the number of people visiting the health facilities to seek medical advice. The Department of Health in South Africa is using various technologies, and social media such as WhatsApp, Short Message Service (SMS) to communicate and update citizens about COVID-19 infections and prevention methods. The government established a WhatsApp group number 0600123456 to communicate COVID-19 related information, people could check their COVID-19 symptoms through the government's official HealthCheck system, and one could dial a toll free number such as *134*832\# to get health related information. The government also used ICTs such as smartphones for COVID-19 patients contact tracing, interactive dashboards were used by the COVID-19 National Command Council to analyse data regarding COVID-19.

In addition to the e-Health and m-Health, the Department of Health has also introduced Telehealth and Telemedicine since 1999. Both Telehealth and Telemedicine are online platforms which allow medical practitioners to consult with patients online, without patients travelling to medical practitioner (Townsend, Scott \& Mars 2019:19). Telemedicine technology is used to offer convenient access medical care services and medicine to South Africans during the COVID-19 lockdown (Board of Healthcare Funders 2020). In addition, e-Pharmacy or ATM-pharmacies are also used in some areas of South Africa to dispense medicine to patients during the lockdown. ATM clinics are supply centres that use robots powered by Artificial Intelligence (AI) to prescribe and dispense medication (Mungadze 2020). Therefore, the South African government can make strides with e-Services, if it was able to resolve basic issues such as illiteracy, poor infrastructure, poor network connection and high costs of data.

\subsection{E-Municipality}

A municipality is typically a single administrative body with legal status, powers and authority for self-governance as provided by the Constitution of the Republic of South Africa (1996). Municipalities in South Africa are categorised into three categories, namely metropolitan, district and local municipalities. Municipalities play a pivotal role in providing services to the citizens in their areas of jurisdictions. The function of municipalities varies from waste disposal, water and sanitation, public healthcare systems, ICT utilities, risk and disaster management, land development, etc. (Magagula, Mukonza, Manyaka \& Moeti 2019). E-Government or e-Municipality has the potential of improving public service delivery in South African municipalities. 
Toots (2007) defines e-Municipality as the use of ICT to communicate valuable information and providing e-Services to citizens in an efficient manner. Miranda, Sanguino and Banegil (2009:431) described e-Municipality as an interactive database system, whereby payments and debt inquiries can be operated electronically.

Due to the COVID-19 pandemic, many municipal services discontinued. However, e-Services continued to operate effectively in different municipalities, even though only restricted operation and queries were permitted in some municipalities because of inadequate ICT infrastructure. Most municipalities only addressed issues related to basic services like electricity, waste disposal, water and sanitation and municipal accounts. Even municipalities with better ICT infrastructure such as e-Tshwane were not able to cope with challenges they are facing during the lockdown. E-Tshwane is part of the City of Tshwane Smart City plan which aims at enhancing customer service by remotely making all resources and communications accessible online. However, only water failures and power loss queries have been attended to by the municipality during the lockdown (Mlangeni 2020). The challenges that most citizens experienced when using the e-Municipality portal during lockdown included long waiting times to receive help from a consultant. Call centres were often overwhelmed with the number of calls because only a few operators were working during the lockdown. Online payments also became a major challenge to illiterate citizens because they lacked knowledge to perform them. Poor people could not benefit from e-Municipal services because they do not have access to smart devices. All these problems point to the fact that municipalities cannot build a Smart City without providing smart devices (self-service centre/customer centre) to the citizens and without providing ICT training to the citizens.

Full e-Services could have been utilised during the national lockdown if the South African government had performed its functions and achieved objectives set in its different ICT related policies and strategies. For example, the high-level implementation plan for national e-Government strategy (2017-2021) aims at establishing the e-Government common service centre, developing monitoring and evaluation strategy for e-Government and developing e-Skills programmes for rural and underserved communities, etc. If the government could have achieved these objectives, e-Government, and e-Governance as well as e-Health and e-Education would not have been major challenges during the national lockdown.

\section{Challenges of e-Government and e-Governance in South Africa}

After exploring the benefits of e-Government and e-Governance, it is imperative to explore the challenges that are associated with e-Government and e-Governance in South Africa. Although the South African government has good policy intentions and, to a certain extent, has been working with various sectors to enforce policy and regulatory frameworks, it has not yet achieved its objective turning South Africa into a Smart Nation. The South African government has made major strides in this regard by spending more capital in ICT infrastructure and broadband network coverage which has assisted in the continuation of access to e-Government and e-Governance during the lockdown, but there are still major challenges facing South African society that government has not yet been able to deal with effectively. For example, Naidoo (2012:64), and Mawelaa, Ochara and Twinomurinzi (2017:159) outline the following challenges:

- Problems of poverty and inequality.

- Corruption, crime, and vandalism of state resource.

- Issues relating to security.

- Lack of access to the internet or ICT infrastructure.

- Stealing of copper cables has significantly impacted e-Governance and compromised the implementation of unbundling policies in South Africa.

- In the technological sector, there are many problems especially with legacy systems and the need to incorporate transversal systems to achieve the horizontal integration needed for cross-departmental integration; and

- The serious shortage of ICT skills and the state's limited capacity to deliver the necessary task force.

Ntulo and Otike (2013:11) state that solid technology infrastructure is required to incorporate the entire e-Government system. Hence, government needs to establish an efficient telecommunications network to provide e-Government services. This is a major challenge, especially in rural areas where there is weak or no network connectivity.

Another major obstacle in e-Government programmes is the scarcity in ICT expertise Naidoo (2012:65). Lack of skilled personnel and insufficient human resource training is a major concern in rural areas because there are no specialists who can help residents access services through the government portal (Smith \& Cohen 2012). 
The ability to use computers and the internet became a critical success factor in the implementation of e-Government, and lack of these abilities will result in marginalisation or even social isolation of the poor and rural areas. People who do not have internet access and smart devices will not be able to benefit from the online services (Khan 2018) envisaged by e-Government initiatives in South Africa. Statistics South Africa (2019) indicates that $64.7 \%$ of South African households had at least one member who had access to, or used the Internet either at home, work, place of study or internet cafés. Marginally, over one-tenth (10.4\%) of South African households had access to the internet at home. The number of people in rural areas who have internet access devices counts to $45 \%$ of the community compared to metro $67.5 \%$ and $63.7 \%$ urban areas. This shows that ICT infrastructure and internet connection in rural areas is still a challenge. Gauteng province has the highest percentage of people who have access to an internet connection with $74.6 \%$ and $16.7 \%$ of households that have access to a home connected network. This indicates that development is taking place in urban areas and cities than in rural areas where only $46.2 \%$ of citizens have access to an internment connection.

The other major problem hampering progress in e-Government in South Africa is lack of access to electricity. ICT infrastructure for e-Government is powered by an electric system. According to Van der Merwe (2019), 84.7\% of South African has access to electricity. This means that about $15,3 \%$ of South African does not have access to electricity. However, not everyone with access to electricity has uninterrupted power supply. South African citizens have been experiencing electricity cuts and load shedding since 2008, but rural areas are worse off than urban areas. According to Seleka (2020:1), residents of an informal settlement called Nomzamo Park claim that the City of Johannesburg has cut off their electricity since June 2019, because of non-payment culture which is prevalent in these communities, and as a result, the community has been staying in darkness for the past 6 months. Therefore, without electricity infrastructure, it will be almost impossible to deal with the digital divide in South Africa. The digital divide is the gap between the accessibility, exposure and use of ICT infrastructure by various members of communities and culture (Van Dijk 2006:222). The digital divide is paramount in South Africa between different social classes, especially between urban people and rural people in the South African communities (Singh 2010:209).

\section{Conclusion}

The objective of this article was to assess the effectiveness of e-Government and e-Governance during national lockdown in South Africa. The main argument was that the main objective of the South African government was to ensure that all citizens have effective and efficient access to e-Services to improve service delivery (e-Governance and e-Government) during the national lockdown in 2020. The above discussion has demonstrated that the use of ICT such as 4IR technologies has led to the improvement of most e-Services in education, e-Health and e-Municipality. The improvements observed in the argument provided in this article are in line with the literature which shows that, not only has the use of technology improved the quality of services provided to citizens, but has also eased the task of providing services and receiving services. However, there is evidence that lack of, or poor ICT infrastructure and internet connection are still hampering e-Government and e-Governance in rural areas. Major efforts have been made during the past 26 years of democracy, but the South African government is still far from achieving its objective of creating a Smart Nation. The government, together with its private sector development partners must develop rural areas and attend to the plight of the poor families in order to ensure equal access to ICT infrastructure in order to avoid exacerbating the current ICT divide.

\section{References}

Barron, P., Peter, J., \& Pillay, Y. (2015). Using Mobile Technology to Improve Maternal, Child and Youth Health and Treatment of HIV Patients. S. Afr Med J, 106(1), 3-4.

Board of Healthcare Funders. (2020). Covid-19- Guideline: Telehealth-Telemedicine-Result-South-African-State-Of-Disaster. Retrieved 18 April 2020, from https://www.bhfglobal.com/2020/03/27/covid-19-telehealth-telemedicine-result-south-african-state-of-disaster

Chen, Y., Dawes, S. S., \& Chen, S. (2017). E-government Support for Administrative Reform in China. In Proceedings of the 18th Annual International Conference on Digital Government Research, ACM.

City of Johannesburg IDP. (2019). Integrated Development Plan 2019/20 Review. Retrieved 18 April 2020, from https://www.joburg.org.za/

Cloete, F. (2012). e-Government Lessons from South Africa 2001 - 2011: Institutions, State of Progress and Measurement. The African Journal of Information and Communication Issue, 7(12), 128-148.

Corruption Watch News. (2019). E-Governance: A Useful Anti-Corruption Tool? Corruption Watch News. Retrieved 19 April 2020, from https://www.corruptionwatch.org.za/e-governance-useful-anti-corruption-tool/ 
Department of Education. (2003). Draft White Paper On E-Education: Transforming Learning and Teaching Through ICT. Pretoria: Government Printer.

Department of Education. (2004). White Paper on E-Education. Pretoria: Government Printers.

Department of Education. (2020). Department of Education's Plans for National Lockdown. Memo DBE Media Conference. Pretoria. Government Printer

Department of Health. (2019). National Digital Health Strategy for South Africa 2019 - 2024. Pretoria: Government Printer.

Department of Telecommunication and Postal Services (DTPS). (2017). National E-Government Strategy and Roadmap. Pretoria: Government Printer.

Dhai, A. (2012). A Health System That Violates Patients' Rights to Access Health Care. South African Journal of Bioethics and Law, 5(4). Retrieved 20 April 2020, from http://www.sajbl.org.za/index.php/sajbl/article/view/216/194

DPSA. (2001). Electronic Government: The Digital Future - Public Service IT Policy Framework. E-government Policy. DPSA. Pretoria: Government Printer. Retrieved 15 June 2020, from https://www.westerncape.gov.za/text/2003/12/egovernmentpolicy.pdf

DPSA. (2019). Prof can you please write the bibliographical referencing of this article because I can't find it on search engines.

Hlangani, A. (2020). Online learning proves crucial during Covid19 lockdown as Vodacom e-school registration spike dramatically. Parent24. Retrieved 20 April 2020, from https://www.parent24.com/Learn/Learning-difficulties/online-learning-proves-crucial-during-covid-19-lockdow n-as-vodacom-e-school-registrations-spike-dramatically-20200414

Karunasena, K., Deng, H., \& Singh, M. (2011). Measuring the Public Value of E-Government: A Case Study from Sri Lanka. Transforming Government: People, Process and Policy, 5(1), 81-99.

Kayembe, C., \& Nel, D. (2019). Challenges and Opportunities for Education in the Fourth Industrial Revolution. African Journal of Public Affairs, 11(3), 79-94.

Khan, H. A. (2018). The Challenges of E-Governance in Public Administration. In Globalization and the Challenges of Public Administration. Palgrave Macmillan, Cham. https://doi.org/10.1007/978-3-319-69587-7_6

Letseka, M., Letseka, M. M., \& Pitsoe, V. J. (2018). The Challenges of E-learning in South Africa. Semantic scholars. https://doi.org/10.5772/intechopen.74843

Lodge, T., \& Mottair, S. (2015). Protest in South Africa: Motives and Meanings, Democratization. Retrieved 21 April 2020, from https://www.researchgate.net/deref/http\%3A\%2F\%2Fdx.doi.org\%2F10.1080\%2F13510347.2015.1030397

Magagula, D. N., Mukonza, R. M., Manyaka, R. K., \&Moeti, K. B. (2019). Towards Strengthening Collaboration Between District and Local Municipalities in South Africa: Insights from Ehlanzeni District Municipality. The Journal for Transdisciplinary Research in Southern Africa, 15(1). https://doi.org/10.4102/td.v15i1.673

Mathevula, M. D., \& Uwizeyimana, D. E. (2014). The Challenges Facing the Integration of ICT in Teaching and Learning Activities in South African Rural Secondary Schools. Mediterranean Journal of Social Sciences, 5(20), 1087-1097.

Mawela, T., Ochara, N. M., \& Twinomurinzi, H. (2017). E-Government Implementation: A Reflection on South African Municipalities. SACJ, 29(1), 147-171.

Meso, P., Musa, P., \& Mbarika, V. (2005). Towards A Model of Consumer Use of Mobile Information and Communication Technology in LDCS: The Case of Sub-Saharan Africa. Information Systems Journal, 15(1), 119-146.

Miranda, F. J., Sanguino, R., \&Banegil, T. M. (2009). Quantitative Assessment of European Municipal Web Sites. Internet Research, 19(4), 425-441.

Mlangeni, P. (2020). Tshwane Assures Residents That Services Will Be Provided During Lockdown. SABC News. $\begin{array}{lllll}\text { Retrieved } & 17 & \text { April } & \text { 2020, from }\end{array}$ https://www.sabcnews.com/sabcnews/tshwane-assures-residents-that-services-will-be-provided-during-lockdow $\mathrm{n} /$ 
Mulyadi, M. S., Anwar, Y., \& Ikbal, M. (2012). The Importance of Corporate Governance in Public Sector. Global Business and Economics Research Journal, 1(1), 25-31.

Mungadze, S. (2020). SA Turns to Telemedicine During COVID-19 Lockdown. Retrieved 21 April 2020, from https://www.itweb.co.za/content/wbrpOqgYbEG7DLZn

Naidoo, G. (2012). Implementation of E-Government in South Africa - Successes and Challenges: The Way Forward. International Journal of Advances in Computing and Management, 1(1), 62-66.

Nalubega, T., \&Uwizeyimana, D. E. (2019). Public sector monitoring and evaluation in the Fourth Industrial Revolution: Implications for Africa. Africa's Public Service Delivery and Performance Review, 7(1), a318. https://doi.org/10.4102/apsdpr.v7i1.318

Ntulo, G., \& Otike, J. (2013). eGovernment: Its role importance and challenges. Kenya, Moi University, School of $\begin{array}{llllll}\text { Information } & \text { Sciences, } & \text { Retrieved } & 18 & \text { April } & \text { 2020, }\end{array}$ http://www.sis.mu.ac.ke/index.php/research.../10-getrude-ntulo

Pillay, K. N. (2012). E-Government in South Africa: Predictors to Failure and Success. Master Dissertation, Johannesburg: University of Witwatersrand.

PSA. (2019). The Era of Fourth Industrial Revolution: Challenges and Opportunities for the Public Service. $\begin{array}{lllll}\text { Retrieved } & 17 & \text { April } & \text { 2020, }\end{array}$ https://www.psa.co.za/docs/default-source/psa-documents/psa-opinion/psa_4th-industrial-revolution-on-publicservants.pdf?sfvrsn=7ad22450_3

Ramaphosa, C. (2020). Statement by President Cyril Ramaphosa On Escalation of Measures to Combat Covid-19 Epidemic. State address by the state President Cyril Ramaphosa. Pretoria: Government Printer.

Reddy, S. (2020). Free Content for Learners During Covid-19 School Closure. Maverick Daily. Retrieved 17 April 2020, https://www.dailymaverick.co.za/article/2020-04-18-free-content-for-learners-during-covid-19-school-closures/

Rimjhim, \& Kumar, V. (2018). Social Implications of E-Government. ResearchGate. Retrieved 19 April 2020, from https://www.researchgate.net/publication/325247975_Social_implications_of_e-government

Roberts, B. H. (2015). The Third Industrial Revolution: Implications for Planning Cities and Regions. Urban Frontiers Working Paper. Tudun Wada: Urban Frontiers.

Schwab, K. (2017). The Fourth Industrial Revolution; Crown Business. New York, NY, USA.

Schwab, K. 2016). The Fourth Industrial Revolution. Retrieved 7 April 2019, from https://www.weforum.org/about/the-fourth-industrial-revolution-by-klaus-schwab

Seleka, N. (2020). Police Fired Rubber Bullets as Soweto Residents Protest Over Electricity Cuts. News24. $\begin{array}{lllll}\text { Retrieved } & 20 & \text { April } & \text { 2020, from }\end{array}$ https://www.news24.com/SouthAfrica/News/police-fire-rubber-bullets-as-soweto-residents-protest-over-electric ity-cuts-20200225

Shafika, I. (2007). ICT in Education in South Africa. Survey of ICT and Education in Africa: South Africa Country Report South Africa. Retrieved 17 April 2020, from www.infodev.org

Singh, S. (2010). The South African 'Information Society', 1994-2008: Problems with Policy, Legislation, Rhetoric and Implementation. Journal of Southern African Studies, 36(1), 209-227.

Statistics South Africa. (2019). General Household Survey. Retrieved 20 April 2020, from http://www.statssa.gov.za/publications/P0318/P03182017.pdf

Statistics South Africa. (2020). South Africa: Digital Population as Of January 2020. Digital Population in South Africa as of January 2020. Retrieved 22 April 2020, from https://www.statista.com/statistics/685134/south-africa-digital-population/

TootS, A. (2007). Take-Up of Municipality E-Services: Some Findings from Citizens' Survey in Tallinn. Retrieved 19 April 2020 ,

from http://www.nispa.sk/_portal/files/conferences/2007/papers/200704231034430.Toots_fulltext_Kyiv_WG_egovm nt.pdf

Townsend, B. A., Scott, R. E., \& Mars, M. (2019). The Development of Ethical Guidelines for Telemedicine in South Africa. South African Journal of Bioethics and Law, 12(1), 19. 
UNPA, ASPA. (2001). Benchmarking e-Government: A Global Perspective. Retrieved 1 May 2020, from http://www.nettelafrica.org/docs/NetTel\%20Safari@the\%20Equator\%20(Uganda\%202003)/Benchmarkingegov t.pdf

Uwizeyimana, D. E. (2011). The effects of party-political interests on policy implementation effectiveness: Low-cost housing allocation in the Cape Town Unicity, 1994-2008. PhD thesis, University of Johannesburg, Johannesburg.

Uwizeyimana, D. E. (2015). Mobile Phones as Means for Extending E-Governance in Rural Areas of Sub-Saharan Africa. African Journal of Public Affairs, 8(4), 151-169.

Uwizeyimana, D. E. (2020). Assessing the need and feasibility of a specific Africa-rooted evaluation approach. Africa's Public Service Delivery and Performance Review (forthcoming).

Uwizeyimana, D. E. (2020a). Africans' contribution to past industrial revolutions and what they can do to contribute to the 4IR. Unpublished Class Notes, University of Johannesburg.

Uwizeyimana, D. E., \& Basheka, B. (2017). The Multidisciplinary, Interdisciplinary and Trans-disciplinary Nature of Public Administration A Methodological Challenge?. African Journal of Public Affairs, 9(9), 1-28.

Uwizeyimana, D. E., \& Maphunye, K. J. (2014). The Changing Global Public Administration and Its Theoretical and Practical Implications for Africa. Journal of Public Administration and Policy Research, 6(4), 90-101.

Van der Merwe, M. (2019). More South Africans Have Access to Electricity, But They're Less Happy About It. Fin24. $\begin{array}{lllll}\text { Retrieved } & 2 & \text { May } & \text { 2020, from }\end{array}$ https://m.fin24.com/Economy/more-south-africans-have-access-to-electricity-but-theyre-less-happy-about-it-20 190528

Van Dijk, J. A. G. M. (2006). Digital Divide Research, Achievements and Shortcomings. Poetics, 34(4-5), 221-235.

Vries, P. (2008). Encyclopaedia of the Modern World. Oxford: Oxford University Press.

White, L., \& Rees, L. (2019, May). Africa Business Brief (Issue 13). JBS Africa Business Brief.

World Health Organization. (2019). WHO Guideline: Recommendations on Digital Interventions for Health System Strengthening. Switzerland: World Health Organization.

Xing, B., \& Marwala, T. (2017). Implications of the Fourth Industrial Age for higher education. The Thinker, 73(n.d), $10-15$.

Xing, B., Marwala, L., \& Marwala, T. (2018). Adopt Fast, Adapt Quick: Adaptive Approaches in the South African Context. In N. Gleason (Ed.), Higher Education in the Era of the Fourth Industrial Revolution. Palgrave Macmillan: Singapore.

\section{Copyrights}

Copyright for this article is retained by the author(s), with first publication rights granted to the journal.

This is an open-access article distributed under the terms and conditions of the Creative Commons Attribution license (http://creativecommons.org/licenses/by/4.0/). 